\title{
Pengaruh Video Pembelajaran Dengan Model Discovery Learning Materi Suhu Dan Kalor Untuk Meningkatkan Aktivitas Siswa
}

\author{
Sandhi Setya Praptama ${ }^{1 *}$, Wahyudha Tri Setiyoaji ${ }^{2}$, Endang Purwaningsih ${ }^{2}$ \\ ${ }^{1}$ SMKN 1 Grati \\ ${ }^{2}$ Jurusan Pendidikan Fisika, Universitas Negeri Malang \\ *Email: sandhispoor@gmail.com
}

Received: 8 September 2021; Accepted: 30 November 2021; DOI: http://dx.doi.org/10.29303/jpft.v7i2.2934

Published: 9 Desember 2021

\begin{abstract}
The aim of this study was to determine the effect of using video-based media on the activities and learning outcomes of physics class $X$ on the subject of temperature and heat at SMK Negeri 1 Grat. As a source of learning, technology is a tool to facilitate learning that is more interesting for students, among the many learning technologies, one of them is video media, which has advantages that are quite good for the implementation of learning. Experimental research used in this research is a quasiexperimental (Quasi Experimental Design) using the Nonequivalent Control Group Design. This design has a control group, but it cannot function to control external variables that affect the implementation of the experiment. Subject of this research are 25. There is a significant effect of using video-based learning media on students' learning activities. Obtained results, the responsibility of students when using video media with the OBS system application obtained an average of 62,25\% at pretest and $82,67 \%$ at posttest, it can be concluded that students are more active in the experimental class than in the control class.
\end{abstract}

Keywords: Video; discovery learning; Learning Activity

\section{PENDAHULUAN}

Saat masa pandemi penulis sangat kesulitan dalam menyampaikan materi pembelajaran di kelas karena bukan keterbatasan sarana dan prasarana dalam melakukan pembelajaran daring dengan menggunakan aplikasi meeting room melainkan penerapan media yang tepat telah melakukan proses kegiatan belajar mengajar. Hal ini disebabkan adanya kendala seperti keterbatasan kuota yang dimiliki oleh siswa ataupun kendala jaringan, sehingga guru kesulitan dalam melakukan penilaian formatif jika tidak ada penilaian yang awalnya dari aktivitas siswa

Di sekolah, tidak sedikit guru yang dalam kegiatan belajar mengajar (KBM) hanya sekedar memberikan tugas saja, terdapat pula guru yang memberikan modul agar siswa membaca sendiri, bahkan memberikan video pembelajaran yang hanya diunduh dari media sosial seperti Youtube, blog, facebook ataupun media yang lain dengan tidak menyesuaikan dengan kondisi psikis siswa ketika pembelajaran di masa pandemi. Padahal, media pembelajaran merupakan salah satu komponen yang memiliki peranan sangat penting didalam pembelajaran, terutama di masa pandemi. Pembelajaran yang berkualitas akan memperoleh hasil belajar siswa yang maksimal. Witherington dalam Rusman (2012) mengatakan bahwa belajar merupakan perubahan dalam kepribadian yang perwujudan sebagai pola-pola respons baru yang berbentuk keterampilan, sikap, kebiasaan, pengetahuan dan kecakapan.

Faktor-faktor yang mempengaruhi prestasi belajar menurut Madonat (2008) ada dua, yaitu faktor internal yang merupakan faktor dari dalam diri siswa yang meliputi : minat, bakat, motivasi, tingkat intelegensi. Faktor eksternal yaitu faktor dari luar siswa yang meliputi kondisi lingkungan 
masyarakat serta lingkungan dan metode belajar. Menurut Sutarto (2008), faktor yang berasal dari luar meliputi faktor-faktor yang berhubungan dengan lingkungan sekolah, lingkungan masyarakat dan lingkungan keluarga, sedangkan faktor yang timbul dalam diri siswa berupa faktor biologis seperti faktor kesehatan misalnya cacat mental, dan faktor psikologisnya seperti kecerdasan, bakat, minat, perhatian serta motivasi belajar siswa. Hasil belajar siswa dipengaruhi oleh berbagai faktor, seperti motivasi belajar, metode pengajaran, sarana dan prasarana yang berupa media pembelajaran. Motivasi belajar merupakan kekuatan (power motivation), daya pendorong (driving force) atau alat pembangun kesediaan dan keinginan yang kuat dalam diri siswa untuk belajar secara aktif, kreatif, efektif, inovatif, dan menyenangkan dalam rangka perubahan perilaku, baik dalam aspek kognitif, afektif maupun psikomotor.

Untuk menunjang keberhasilan dan hasil belajar siswa dalam proses pembelajaran, guru memerlukan sarana guna dapat menyampaikan materi dengan baik maupun menarik sehingga dapat dipahami oleh siswa nya. Kini teknologi dalam pembelajaran bisa menjadi sarana pembelajaran, media, dan sumber belajar bagi siswa. Sebagai sumber belajar, teknologi merupakan alat untuk memperlancar pembelajaran yang lebih menarik bagi siswa, sehingga dimungkinkan pula dapat memperoleh hasil belajar yang sesuai dengan harapannya. Di antara banyak teknologi pembelajaran salah satunya adalah dengan media video, yang memiliki kelebihan cukup baik untuk pelaksanaan pembelajaran.

Oleh sebab itu, bagaimanakah cara meningkatkan aktivitas siswa dengan menggunakan media pembelajaran yang tepat. Media pembelajaran yang tepat tersebut akan menambah tingkat psikologi siswa dan merasakan bahwa gurunya ada dan sedang mengajar, bukan hanya memberikan tugas membaca dan memberikan tugas. Namun, beberapa kasus yang penulis amati sebagian besar guru hanya berkutat dengan media modul yang memang mudah diakses tetapi masih belum membawa guru ke dalam pembelajaran. Penulis memilih media belajar berbasis multimedia yaitu video pembelajaran. Hal ini dimaksudkan, dengan siswa mengunduh video pembelajaran siswa diharapkan masih bisa merasakan guru tetap melakukan kegiatan belajar mengajar. Kelebihannya materi bisa diunduh kapan saja, dan juga bisa disalin untuk siswa lainnya, walaupun kekurangannya pun juga ada pemantauan keaktifan siswa secara langsung masih lemah.

Media video pembelajaran merupakan suatu perantara yang disusun dengan komponen visual dan audio yang dapat membangun keterampilan, pemahaman guna mencapai tujuan pembelajaran (Hayati \& Harianto, 2017). Kemudian menurut Mahadewi, et al. (2012) video pembelajaran merupakan media yang digunakan untuk merangsang siswa untuk belajar melalui penayangan materi secara audio visual. Menurut Daryanto (2018) terdapat beberapa keunggulan dan kelemahan penggunaan media video pembelajaran yaitu 1) Dalam video ditampilkan gambar bergerak yang menyertai suara, sehingga video menambah suasana baru dalam pembelajaran, 2) Beberapa penjelasan yang sulit dijelaskan secara langsung atau nyata dapat ditampilkan melalui video. Kemudian adapun kelemahannya yaitu 1) Biaya yang digunakan untuk membuat video memerlukan biaya yang tidak sedikit, 2) Apabila penyampain materi yang ditampilkan dalam video kurang tepat, maka akan menimbulkan keraguan penonton dalam menafsirkan maksud video tersebut. 
Metode pembelajaran yang dapat digunakan bersama dengan video pembelajaran ialah metode discovery learning.

Model discovery learning adalah metode yang membuat siswa mempelajari serta mengorganisasi sendiri materi yang telah diberikan oleh guru (Sulfemi \& Yuliana, 2019). Model discovery learning sudah merupakan suatu konsep yang digunakan siswa untuk memperoleh informasi dengan cara observasi atau percobaan (Cintia et al., 2018). Dalam pelaksanaannya proses pembelajaran lebih berpusat pada siswa (student center) yang dituntut untuk memecahkan masalah serta mengeksplorasi pengetahuan yang dibutuhkan. Penerapan pada kelas yang akan dijadikan subjek penelitian menggunakan materi suhu dan kalor, pada penelitian sebelumnya juga diterapkan materi suhu kalor, akan tetapi media pembelajaran yang digunakan ialah virtual laboratory (Setiyoaji et al., 2021).

Suhu dan kalor dipilih karena merupakan salah satu konsep dalam fisika. Konsep suhu dan kalor sudah diperoleh siswa sejak duduk di bangku sekolah dasar, sekolah menengah, sampai perguruan tinggi dalam kurikulum mata pelajaran IPA, khususnya fisika (Budiarti et al., 2017). Menurut Baser (2006), siswa mengalami kesulitan pada konsep perpindahan kalor secara konduksi yang terjadi pada selt belt yang terbuat dari logam dan non logam. Kecenderungan siswa untuk menghafalkan konsep perpindahan kalor tanpa disertai contoh konkrit, menyebabkan hasil belajar siswa menjadi rendah (Sisila \& Siregar, 2017). Hal ini didukung oleh Sözbilir (2003), bahwa siswa mengalami kesulitan untuk mempelajari konsep suhu dan kalor karena konsep suhu dan kalor terlalu abstrak. Dengan demikian, konsepsi suhu dan kalor penting dipahami oleh siswa agar tidak menimbulkan miskonsepsi.
Tujuan penelitian ini untuk mengetahui 1) Pengaruh penggunaan media berbasis video terhadap aktivitas belajar Fisika kelas X pada pokok bahasan Suhu dan Kalor di SMK Negeri 1 Grati, 2) Pengaruh penggunaan media berbasis video terhadap hasil belajar Fisika kelas X pada pokok bahasan Suhu dan Kalor di SMK Negeri 1 Grati.

\section{METODE PENELITIAN}

Dalam penelitian ini metode penelitian yang digunakan adalah metode eksperimen, dimana metode eksperimen menurut Sugiyono (2012). merupakan metode yang menjadi bagian dari metode kuantitatif yang mempunyai ciri khas tersendiri, yaitu dengan adanya kelas kontrol dan kelas eksperimen. Jenis penelitian eksperimen yang digunakan dalam penelitian ini adalah experimental semu (Quasi Experimental Design). Desain ini mempunyai kelompok kontrol, tetapi tidak dapat berfungsi untuk mengontrol variabelvariabel luar yang mempengaruhi pelaksanaan eksperimen Sugiyono (2012: 114). Dengan menggunakan Nonequivalent Control Group Design yang terdapat dua kelompok yag dipilih kemudian diberi pretest untuk mengetahui keadaan awal dakah perbedaan antara kelompok

\begin{tabular}{ccc}
\hline $\mathrm{O}_{1}$ & $\mathrm{X}$ & $\mathrm{O}_{2}$ \\
\hline $\mathrm{O}_{3}$ & & $\mathrm{O}_{4}$ \\
\hline Pretest & Treatment & Posttest
\end{tabular}

\begin{tabular}{ccr}
\hline Pretest & Treatment & Posttest \\
\hline Gambar 1. Model Penelitian One-Group \\
Pretest-Posttest
\end{tabular}

Berdasarkan gambar 1 Model Penelitian One-Group Pretest-Posttest diatas $\mathrm{O}_{1}$ adalah nilai awal kelas eksperimen $\mathrm{X}$ ATU 1 (Agribisnis Ternak Unggas 1), dan $\mathrm{O}_{3}$ adalah nilai awal kelas kontrol X KI 1 (Kimia Industri 1). O1 dan O3 sama-sama diberikan pretest, akan tetapi kelompok yang diberikan treatment merupakan O1. Treatment yang 
diberikan pada O1 merupakan pemberian video model pembelajaran dengan model discovery learning. Kemudian $\mathrm{O}_{2}$ adalah hasil kelas eksperimen X ATU 1 (Agribisnis Ternak Unggas 1) dan $\mathrm{O}_{4}$ adalah hasil kelas control X KI 1 (Kimia Industri 1).

Subjek penelitian ini adalah siswa di SMK Negeri 1 Grati yang menempuh materi Suhu dan Kalor. Sebagai pemilihan kelas kontrol adalah kelas X KI 1 (Kimia Industri 1) dan kelas eksperimen adalah $X$ ATU 1 (Agribisnis Ternak Unggas 1). Pemilihan kedua kelas ini berdasarkan dari hasil pretest dan diolah untuk dicari tingkat homogenitasnya sehingga dipilih kedua kelas tersebut.

Untuk Validasi yang memang harus dilakukan pada setiap penelitian untuk medapatkan masukkan dan tanggapan yang positif dari pengembangan media yang dilakukan. Para validator merupakan orang yang melakukan kegiatan validasi, dimana pada penelitian ini menggunakan 3 jenis validasi yaitu validasi desain pembelajaran, validasi ahli materi dan validasi pengguna yakni siswa. Untuk validator desain yaitu guru yang telah memiliki sertifikat profesional bidang pendidikan berkompetensi dari pembelajaran Fisika ataupun yang berkompetensi di dalam pembelajaran. Validator ahli materi adalah guru yang berkompetensi dalam bidang Fisika maupun guru yang ahli dalam pembuatan media pembelajaran ataupun yang berkompetensi di bidang materi pembelajaran fisika. Siswa yang bertindak sebagai validator pengguna atau user pada kelas eksperimen

Kegiatan ini bertujuan untuk meningkatkan aktivitas siswa pada pembelajaran daring di masa pandemi dengan menggunakan media video pembelajaran suhu dan kalor dalam menyusun materi ajar sesuai kebutuhan kelas mereka. Setiap siswa akan diberikan pretest dan posttest kemudian hasil tersebut kemudian dibandingkan untuk diambil kesimpulan terhadap pemahaman para siswa. Pretest dan posttest menggunakan soal pilihan berganda dengan jumlah masingmasing soal adalah 10 soal. Rancangan penelitian terhadap kegiatan ini ditunjukkan pada Tabel 1 sebagai berikut:

Tabel 1. Rancangan Kegiatan Penelitian

\begin{tabular}{|c|c|c|}
\hline PreTest & Treatment & PostTest \\
\hline $\begin{array}{lr}\begin{array}{l}\text { Mengukur } \\
\text { pengetahuan }\end{array} \\
\text { siswa para } \\
\text { kemampuan } \text { terkait } \\
\text { siswa awal } \\
\text { menjawab beberapa } \\
\text { soal yang sudah } \\
\text { disediakan. Soal } \\
\text { terdiri dari } 10 \text { soal } \\
\text { pertanyaan pilihan } \\
\text { ganda dengan } \\
\text { berbantukan aplikasi } \\
\text { google form. }\end{array}$ & $\begin{array}{l}\text { - Kegiatan pendidikan dilakukan secara daring saat jam } \\
\text { pelajaran berlangsung yaitu siswa menyimak video } \\
\text { pembelajaran yang dibuat guru dengan menggunakan } \\
\text { aplikasi OBS System dan diunggah pada media Youtube } \\
\text { dengan settingan unlisted. Unlisted ini berguna hanya } \\
\text { orang yang diberi link untuk masuk saja yang bisa } \\
\text { menonton video. Kemudian siswa dapat melakukan } \\
\text { presensi dan menjawab pertanyaan dikolom komentar. } \\
\text { Kemudian siswa didalam tugas tersebut diberikan tugas } \\
\text { sebagai tugas harian untuk diamati aktivitas selanjutnya. } \\
\text { Tugas diberikan ada didalam video tersebut (sehingga } \\
\text { siswa tidak melompati video) }\end{array}$ & $\begin{array}{l}\text { Mengukur pengetahuan } \\
\text { para siswa terkait } \\
\text { kemampuan siswa setelah } \\
\text { menonton video. dengan } \\
\text { cara menjawab soal soal } \\
\text { yang sudah disediakan. } \\
\text { Soal terdiri dari } 10 \text { soal } \\
\text { pertanyaan Pilihan } \\
\text { Berganda. }\end{array}$ \\
\hline
\end{tabular}

Teknik pengumpulan data yang digunakan yaitu dokumentasi, teknik tes, observasi, dokumen digunakan untuk memperoleh data siswa yang akan menjadi sampel dalam penelitian ini, pada metode ini menggunakan alat tangkap layar (baik menggunakan sarana komputer maupun smartphone) dan direkap guna mempeoleh 
data yang tersedia, data yang diperolah adalah nilai siswa kelas $X$. Teknik tes digunakan untuk mengevaluasi hasil belajar siswa setelah proses pembelajaran. Pembelajaran berlangsung dalam dua kali pertemuan. Sedangkan tes dilakukan pada akhir pertemuan, bentuk tes yang diberikan pada saat uji coba adalah pilihan ganda sebanyak 10 soal. dengan memberikan nilai 10 jika siswa menjawab soal yang benar dan memberikan nilai 0 untuk siswa yang menjawab soal yang salah, sehingga jika siswa dapat menjawab semua soal, akan mendapatkan nilai 100 .

Observasi dilakukan selama pembelajaran hingga akhir pembelajaran untuk melihat aktivitas belajar siswa, sehingga akan terlihat keaktifan pada tiap diri siswa sehingga mudah untuk melakukan evaluasi Teknik analisis data yang digunakan untuk melihat pengaruh penggunaan media pembelajaran berbasis video terhadap aktivitas dan hasil belajar siswa adalah menggunakan uji t, dengan rumus yang dikemukakan oleh Seniati et al. (2015). Kemudian dilanjutkan dengan melakukan uji $\mathrm{N}$-gain yang digunakan untuk melihat peningkatan aktivitas siswa setelah diberikan media video pembelajaran mengenai materi suhu dan kalor.

\section{HASIL DAN PEMBAHASAN}

Video pembelajaran pada materi Suhu dan Kalor diunggah kepada di situs Youtube pada kanal yang dimiliki peneliti yaitu channel sandhispoor yang di-setting menjadi didalam bentuk unlisted. Tujuan di setting seperti itu adalah hanya orang yang diberi link untuk masuk saja yang bisa menonton video. Kemudian siswa dapat melakukan presensi dan menjawab pertanyaan dikolom komentar. Hasil dari video dan hasil dari presensi dan menjawab pertanyaan ada di gambar 1 dan gambar 2 .

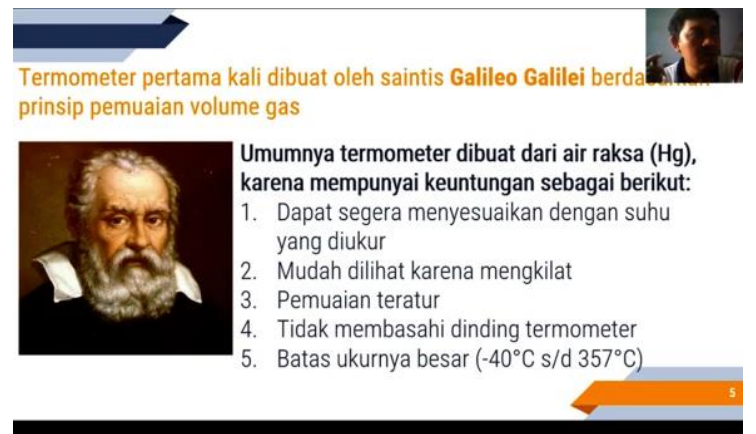

Gambar 1. Tampilan Video pembelajaran di Youtube

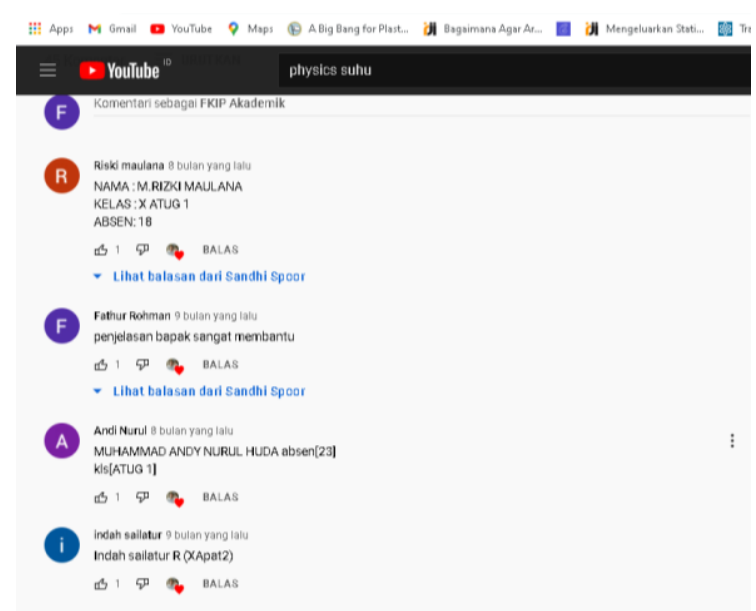

Gambar 2. Tampilan Komentar di Youtube

$\begin{array}{ccc}\text { Hasil pengujian } & \text { hipotesis } \\ \text { membuktikan } & \text { bahwa ada pengaruh }\end{array}$ signifikan penggunaan media pembelajaran video $(\mathrm{X})$ terhadap aktivitas belajar siswa (Y1), dengan perhitungan Thitung > Ttabel yaitu 3,788> 1,988. Berdasarkan uji hipotesis dan analisis data yang sudah dilakukan bahwa media pembelajaran berbasis video dengan aplikasi OBS System dan diunggah pada media Youtube mempengaruhi aktivitas belajar siswa. Aktivitas yang diamati dalam kegiatan pembelajaran dengan menggunakan media pembelajaran berbasis video dan tanpa menggunakan media berbasis video yang terdiri dari 5 jenis penilaian yaitu memperhatikan materi yang disampaikan oleh guru, mencatat materi yang disampaikan oleh guru, bertanya kepada guru (baik melalui Whatsapp Group ataupun melalui kolom komentar di Youtube), 
menjawab pertanyaan guru, dan mengerjakan soal yang diberikan oleh guru. Pada pertemuan ini siswa masih belum bisa memahami dan masih belum terbiasa dalam menggunakan media pembelajaran berbasis video.

Pada pembelajaran tatap muka biasanya menggunakan ceramah dan berdiskusi dengan menggunakan pembelajaran kooperatif yang menuntut keaktifan siswa dalam pembelajaran di kelas, selain itu masih banyak siswa yang tidak berani bertanya dan menangapi pertanyaan baik yang disampaikan oleh guru maupun dari siswa lain, ini juga merupakan faktor penyebab kurang aktifnya siswa dalam belajar apalagi ini diterapkan pada pembelajaran daring di masa pandemi. Begitu pula pada pembelajaran jarak jauh (PJJ) jika dilakukan sama seperti halnya pembelajaran tatap muka, tidak sedikit siswa yang menanggapi pertanyaan, atau tugas yang diberikan guru.

Berdasarkan hasil observasi siswa yang memperhatikan materi yang disampaikan oleh guru sudah cukup baik, mencatat rangkuman materi yang disampaikan oleh guru, bertanya kepada guru (melalui WAG), dan menjawab pertanyaan guru. Namun ada beberapa kendala dalam menggunakan media berbasis video ini, diantaranya seperti pulsa untuk paketan data, sinyal yang susah, dan piranti pemutar video yang tidak ada (karena memang ada beberapa siswa yang kurang mampu).

Pada petemuan ini aktivitas siswa siswa yang memperhatikan materi menggunakan media video sudah cukup baik, hanya ada beberapa siswa yang harus diingatkan untuk dapat mengakses video melalui kanal Youtube, selain itu siswa yang mencatat materi yang disampaikan oleh guru sebanyak 53\%, bertanya kepada guru sebanyak $16 \%$, menjawab pertanyaan guru sebanyak $43 \%$ dan pada pertama ini belum diadakan tes soal.

Rendahnya aktivitas belajar siswa yang diperoleh pada pertama ini dikarenakan siswa belum terbiasa dengan menggunakan media belajar menggunakan video dan juga video yang di tayangkan melalui kanal YouTube susah dicari jika siswa tidak diberi link untuk membuka. Pembelajaran jarak jauh (PJJ) biasanya menggunakan ceramah dan berdiskusi dengan menggunakan pembelajaran kooperatif yang menuntut keaktifan siswa dalam pembelajaran di kelas, selain itu masih banyak siswa yang tidak berani bertanya dan menangapi pertanyaan baik yang disampaikan oleh guru maupun dari siswa lain atau juga mereka malas menanggapi karena media yang diberikan guru terkesan membosankan, ini juga merupakan faktor penyebab kurang aktifnya siswa dalam belajar.

Sedangkan pada pertemuan ke-1 kegiatan tanpa menggunakan media pembelajaran berbasis video sudah dapat terlaksanakan, masih banyak aktivitas belajar siswa masih sangat sedikit, dikarenakan proses pembelajaran hanya menggunakan media power point dan modul elektronik yang itu membuat siswa merasa jenuh dan bosan. Selain itu pada saat pembelajaran siswa cenderung ribut, banyak siswa yang bermain dan mengobrol dengan teman sebangku, jalan-jalan dikelas, keluar masuk kelas dengan alasan pergi ke kamar mandi, tidur didalam kelas dan kurang memperhatikan materi yang disampaikan oleh guru.

Pelaksanaan pembelajaran pada pertemuan ke-2 dengan menggunakan media berbasis video ini berjalan sudah lebih efektif karena siswa sudah mulai berani untuk mengungkapkan pendapat baik untuk bertanya maupun menanggapi pertanyaan dari guru maupun dari siswa lain, selain itu siswa sudah mampu untuk mengaitkan 
materi dengan fenomena yang terjadi pada lingkungan mereka. Pada pertemuan ke-2 ini siswa juga sudah mampu mengikuti pembelajaran dengan baik, dan siswa juga lebih antusias untuk mengikuti pembelajaran, bahkan sudah terjadi debat antar siswa setelah melihat tayangan video yang di putar.

Pada kelas kontrol (dipilih kelas yang memiliki intake bagus) banyak siswa yang memperhatikan materi yang disampaikan tetapi menggunakan media power point, bahkan guru memberikan perlakuan seperti biasanya. Berdasarkan analisis di atas pada kelas ekperimen dan kelas kontrol dapat disimpulkan bahwa aktivitas belajar siswa dengan menggunakan media berbasis video dapat meningkatkan aktivitas belajar siswa.

Selain itu, respon siswa terhadap guru terhadap pembelajaran dengan menggunakan video pembelajaran sebelum dan sesudah kegiatan belajar mengajar memiliki perbedaan yang hasilnya menjadi lebih baik dengan masing-masing prosentase $62.25 \%$ (sebelum pembelajaran) dan 82,67 $\%$ (sesudah pembelajaran) dijelaskan pada tabel 4. Pada hasil aktivitas siswa, hasil pretest-postest pada penelitian ini dipaparkan pada tabel 4.

Tabel 4. Responsibilitas peserta didik ketika menggunakan media video dengan aplikasi OBS System

\begin{tabular}{lll}
\hline Pertanyaan & $\begin{array}{l}\text { Sebelum } \\
\text { Pembelaja } \\
\text { ran (\%) }\end{array}$ & $\begin{array}{l}\text { Sesudah } \\
\text { Pembelaja } \\
\text { ran (\%) }\end{array}$ \\
\hline $\begin{array}{l}\text { Mengajak siswa } \\
\text { untuk mencari tahu }\end{array}$ & 61.67 & 81.67 \\
\hline $\begin{array}{l}\text { Mengajak siswa } \\
\text { untuk membuktikan }\end{array}$ & 60.83 & 79.17 \\
\hline $\begin{array}{l}\text { Menyiapkan/membe } \\
\text { rikan masalah } \\
\text { kepada siswa }\end{array}$ & & 80.83 \\
\hline $\begin{array}{l}\text { Membiasakan siswa } \\
\text { untuk }\end{array}$ & \\
$\begin{array}{l}\text { mengidentifikasi } \\
\text { permasalahan }\end{array}$ & 84.17 \\
\hline
\end{tabular}

\begin{tabular}{lll}
\hline Pertanyaan & $\begin{array}{l}\text { Sebelum } \\
\text { Pembelaja } \\
\text { ran (\%) }\end{array}$ & $\begin{array}{l}\text { Sesudah } \\
\text { Pembelaja } \\
\text { ran (\%) }\end{array}$ \\
\hline $\begin{array}{l}\text { Mengajak siswa } \\
\text { untuk mengamati }\end{array}$ & 65 & 85 \\
\hline $\begin{array}{l}\text { Memotivasi siswa } \\
\text { untuk menanya }\end{array}$ & 64.17 & 83.33 \\
\hline $\begin{array}{l}\text { Memotiviasi siswa } \\
\text { untuk }\end{array}$ & 65 & 83.33 \\
$\begin{array}{l}\text { mengumpulkan } \\
\text { informasi, }\end{array}$ & \\
\hline $\begin{array}{l}\text { Memotivasi siswa } \\
\text { untuk mengasosiasi } \\
\text { (menalar) }\end{array}$ & 62.5 & 81.67 \\
\hline $\begin{array}{l}\text { Memotivasi siswa } \\
\text { untuk }\end{array}$ & 59.17 & 83.33 \\
$\begin{array}{l}\text { menyimpulkan/men } \\
\text { coba }\end{array}$ & & \\
\hline $\begin{array}{l}\text { Membiasakan siswa } \\
\text { bekerja } \\
\text { berkolaborasi }\end{array}$ & 63.33 & 84.17 \\
\hline $\begin{array}{l}\text { Rata-Rata (\%) } \\
\text { (\%) }\end{array}$ & $\mathbf{6 2 . 2 5}$ & \\
\hline & & \\
\hline
\end{tabular}

Tabel 5. Hasil aktivitas siswa, pretest-postest

\begin{tabular}{lllll}
\hline Data & \multicolumn{2}{l}{$\begin{array}{l}\text { Kelas } \\
\text { kontrol }\end{array}$} & \multicolumn{2}{l}{$\begin{array}{l}\text { Kelas } \\
\text { Eksperimen }\end{array}$} \\
& Pre & Post & Pre & Post \\
\hline Nilai Max & 60 & 90 & 20 & 90 \\
\hline Nilai Min & 20 & 60 & 50 & 70 \\
\hline Rata - rata & 43 & 75 & 36 & 80 \\
\hline $\begin{array}{l}\text { Tingkat } \\
\text { Keberhasilan } \\
(\%)\end{array}$ & 11,1 & 77,78 & 0 & 80,55 \\
$\begin{array}{l}\text { Tingkat } \\
\text { Aktivitas rata- } \\
\text { rata }\end{array}$ & & & & \\
\hline
\end{tabular}

Dari data yang dipaparkan diatas sesuai dengan pendapat dengan Rusman (2012) menyatakan bahwa manfaat media pembelajaran dalam pembelajaran akan lebih bervariasi, tidak semata-mata komunikasi verbal melalui penunturan katakata oleh guru, sehingga siswa tidak bosan dan guru tidak kehabisan tenaga, apalagi bila guru harus mengajar untuk setiap jam pelajaran, siswa lebih banyak melakukan kegiatan belajar, sebab tidak hanya mendengar uraian guru, tetapi juga aktivitas lain seperti mengamati, melakukan, dan mendemonstrasikan. 
Menurut Miller dalam Suyatna (2008) program video sebagai media pembelajaran memiliki beberapa kelebihan antara lain dapat dilihat dan didengar secara berulang, memberi stimulus secara simultan terhadap berbagai indera (melihat dan mendengar), serta membantu kejelasan infromasi dan memori. Dengan demikian video dapat membantu para guru untuk mengetahui satu pendekatan baru yang bisa digunakan untuk menarik minat belajar. Video juga dapat menjadi salah satu alternatif dalam mengatasi kemerosotan pembelajaran. Pebelajar bisa menggunakan video untuk meningkatkan daya kreativitas dalam proses penyampaian isi-isi pengajaran supaya menjadi lebih berkesan dan mudah, sesuai dengan karakteristik pelajar. Hal ini sejalan dengan penelitian Kristanto (2010) yang menyatakan bahwa penggunaan video pembelajaran mampu meningkatkan pemahaman materi dan sudah memenuhi kategori "sangat baik" dan layak digunakan dalam pembelajaran.

Oleh karena itu, makin baik media video diterapkan dalam pembelajaran, makin baik pula aktivitas belajar siswa (Hidayat, et. al., 2018). Taufikurachman et al. (2018) menyatakan bahwa aktivitas belajar siswa dalam kegiatan pembelajaran, hakekatnya antara guru, siswa, dan interaksi antara guru dan siswa sangatlah menunjang terhadap tercapainya suatu tujuan pembelajaran yang baik. Guru sebagai seorang pemimpin didalam kelas harus mampu menciptakan serta mengelola suasana belajar yang kodusif. Bahkan mengkondisikan siswa untuk lebih aktif dalam proses pembelajaran melalui penggunaan media belajar yang tepat. Sementara itu, siswa dengan berbagai latar belakang dan situasi emosiaonal yang berbeda-beda ketika di kelas harus dikondisikan.
Hal tersebut agar mereka benar-benar mengalami dengan di namakan proses pembelajaran dengan berbagai jenis aktivitas belajarnya. Pada akhirnya bertujuan untuk mencapai proses belajar yang telah direncanakan sebelumnya. Mengajar efektif yaitu kemahiran (guru) dalam menyajikan bahan pelajaran dengan meramu (berbagai) penggunaan metode mengajar. Strategi dan metode pembelajaran hendaknya mempertimbangkan prinsipprinsip: (1) orientasi pada tujuan; (2) aktivitas belajar; (3) individualisasi; dan (4) integritas (keseluruhan pribadi siswa). Hasil belajar dipengaruhi oleh beberapa faktor. Faktor eksternal yang mempengaruhi hasil belajar siswa salah satunya adalah media dalam pembelajaran (Turyati, et. al., 2016). Oleh karena itu, analisis ini bisa menjadi pertimbangan bagi guru saat memutuskan untuk menerapkan suatu media pembelajaran secara efektif di kelas demi tercapainya tujuan pembelajaran.

\section{PENUTUP}

Kesimpulan pada penelitian ini adalah terdapat pengaruh yang signifikan penggunaan media pembelajaran berbasis video terhadap aktivitas belajar siswa. Siswa yang aktif pada kelas eksperimen lebih banyak dari pada kelas kontrol. Selain itu, terdapat pengaruh yang signifikan penggunaan media pembelajaran berbasis video terhadap hasil belajar Fisika pada materi Suhu dan Kalor. Hasil belajar siswa yang menggunakan media berbasis video (kelas eksperimen) lebih tinggi dari pada hasil belajar siswa yang tidak menggunakan media berbasis video (kelas kontrol).

\section{REFERENSI}

Baser, M. (2006). Fostering Conceptual Change by Cognitive Conflict Based Instruction on Students' Understanding of Heat And 
Temperature Concepts. Eurasia Journal of Mathematics, Science and Technology Education, 2(2), 96114

Budiarti, Slamet, I., Suparmi, Sarwanto, \& Harjana. (2017). Students' Conceptual Understanding Consistency of Heat And Temperature. Journal of Physics: Conf. Series, 795, 012051. https://doi.org/10.1088/1742$\underline{6596 / 755 / 1 / 011001}$

Cintia, N. I., Kristin, F., \& Anugraheni, I. (2018). Penerapan Model Pembelajaran Discovery Learning Untuk Meningkatkan Kemampuan Berpikir Kreatif Dan Hasil Belajar Siswa. Perspektif Ilmu Pendidikan, 32(1), $67 \quad-\quad 75$. https://doi.org/10.21009/PIP.321.8

Daryanto. (2018). Media Pembelajaran. Yogyakarta: Gava Media.

Hayati, N., \& Harianto, F. (2017). Hubungan Penggunaan Media Pembelajaran Audio Visual dengan Minat Peserta Didik pada Pembelajaran Pendidikan Agama Islam di SMAN 1 Bangkinang Kota.Al-Hikmah: Jurnal Agama Dan Ilmu Pengetahuan, 14(2), 160-180.

Hidayat, D., Wiharna, O., \& Yayat, Y. (2018). Pengaruh Penggunaan Video Pembelajaran Terhadap Hasil Belajar Siswa Pada Materi Garis Dan Konstruksi Geometris. Journal of Mechanical Education, 5(2), 163-168.

Kristanto, A. (2010). Pengembangan Model Media Video Pembelajaran Mata Kuliah Pengembangan Media Video/TV Program Studi Teknologi Pendidikan Fakultas Ilmu Pendidikan Universitas Negeri Surabaya. Jurnal Teknologi Pendidikan, 11:12-22.

Mahadewi, L. P. P., Tastra, I. D. K., \& Sudarma, I. K. (2012). Media Video Pembelajaran. Singaraja: Universitas Pendidikan Ganesha.
Rusman. (2012).

Model-model Pembelajaran. Raja Grafindo, Jakarta.

Seniati, L., Yulianto, A., \& Setiadi, B. N. (2015). Psikologi Eksperimen (Sebastianus Darwin, Ed). Jakarta: PT Indeks.

Setiyoaji, W. T., Supriana, E., Latifah, E., Purwaningsih, E., \& Praptama, S. S. (2021). The Effect of Learning Simulation Media on the Students' Critical Thinking Skills in Vocational School during Online Learning in the Covid-19 Pandemic. Jurnal Pendidikan Fisika, 9(3), 243252.

Sisila, A., \& Siregar, T. (2017). Pengaruh Penggunaan Media Kit IPA Terhadap Motivasi Dan Hasil Belajar Siswa Pada Materi Hantaran Panas Pada Benda Kelas VI Sekolah Dasar Negeri 03 Nabire. Jurnal Ilmu Pendidikan Indonesia, 5(1), 1-13;

Sözbilir, M. (2003). A Review Of Selected Literature on Students' Misconceptions of Heat And Temperature. Boğaziçi Üniversitesi Ĕ̈itim Dergisi, 20(1), 25-41.

Sugiyono. (2012). Metode Penelitian Pendidikan. Bandung: Alfabeta.

Sulfemi, W. B., \& Yuliana, D. (2019). Penerapan Model Pembelajaran Discovery Learning Meningkatkan Motivasi dan Hasil Belajar Pendidikan Kewarganegaraan. Jurnal Rontal Keilmuan., 5(1), 1730.

Sutarto, E. (2008). Moving Class Dan Motivasi Belajar Mempengaruhi Prestasi Belajar. http://386_M0ving Class.Pdf. Diakses 25 Mei 2021.

Suyatna, A. (2008). Pemanfaatan Multimedia Untuk Pembelajaran Sains Bermuatan Nilai. In Prosiding: Seminar Nasional Sains, Univ. Lampung.

Taufikurachman, I. E., Kusumah, I. H., \& Permana, T. (2018). Penggunaan 
Media Video Pada Mata Pelajaran Pekerjaan Dasar Teknik Otomotif di Sekolah Menengah

Kejuruan. Journal of Mechanical Engineering Education, 6(1), 57-63.

Turyati, T., \& Muchtarom, M. Pengaruh Penggunaan Media Video Edukasi Terhadap Hasil Belajar Pkn Siswa Kelas VII SMP Negeri 2 Gondangrejo. PKn Progresif, 11(1), 159311. 